\title{
Partial vs. radical nephrectomy and the risk of all-cause mortality, cardiovascular, and nephrological outcomes
}

\author{
Rodney H. Breau ${ }^{1}$; Anil Kapoor ${ }^{2}$; Danielle M. Nash ${ }^{3}$; Neal Rowe ${ }^{1}$; Octav Cristea ${ }^{1}$; \\ Garson Chan ${ }^{4}$; Stephanie N. Dixon ${ }^{3}$; Eric McArthur ${ }^{3}$; Camilla Tajzler²; Ravi Kumar ${ }^{1}$; \\ Christopher Vinden ${ }^{4}$; Jonathan Izawa ${ }^{4}$; Amit X. Garg ${ }^{3,5}$; Patrick P. Luke \\ ${ }^{1}$ The Ottawa Hospital Research Institute, Division of Urology, University of Ottawa, Ottawa, ON, Canada; \\ ${ }^{2}$ McMaster University, Hamilton, ON, Canada; ${ }^{3} \mathrm{ICES} ;{ }^{4}$ Divisions of Urology and General Surgery, Department of \\ Surgery Western University, London, ON, Canada; ${ }^{5}$ Division of Nephrology, Department of Medicine, Western \\ University, London, ON, Canada
}

Acknowledgments: The use of ICES data in this project was authorized under section 45 of Ontario's Personal Health Information Protection Act, which does not require review by a Research Ethics Board.

Cite as: Can Urol Assoc J 2020 May 12; Epub ahead of print. http://dx.doi.org/10.5489/cuaj.6436

Published online May 12, 2020

$* * *$

\section{Abstract}

Introduction: The study's objective was to examine the effects of renal preservation surgery on long-term mortality, cardiovascular outcomes, and renal-related outcomes.

Methods: We performed a retrospective cohort study of all partial $(\mathrm{n}=575)$ and radical nephrectomies $(\mathrm{n}=882)$ for tumors $\leq 7 \mathrm{~cm}$ in diameter between 2002 and 2010 across three academic centers in Ontario, Canada. We linked records from provincial databases to assess patient characteristics and outcomes (median seven years' followup using retrospective data). A weighted propensity score was used to reduce confounding. The primary outcome was all-cause mortality. Secondary outcomes included hospitalization with major cardiovascular events, noncancer related mortality, kidney cancer-related mortality, and dialysis.

Results: Mean one-year postoperative estimated glomerular filtration rate (eGFR) was 71 $\mathrm{mL} / \mathrm{min} / 1.73 \mathrm{~m}^{2}$ in the partial group and $52 \mathrm{~mL} / \mathrm{min} / 1.73 \mathrm{~m}^{2}$ in the radical group. Partial nephrectomy was associated with a lower risk of all-cause mortality in the first five years after surgery (hazard ratio [HR] 0.42; 95\% confidence interval [CI] 0.27-0.66), which did not extend beyond five years (HR 1.01; 95\% CI 0.68-1.49). Kidney cancer-related mortality was lower in the partial compared to the radical group for the first four years after surgery (HR 0.16; $95 \% \mathrm{CI}$ 
0.04-0.72). There were no significant differences between the groups for cardiovascular outcomes or non-cancer related deaths.

Conclusions: Overall survival and cancer-specific survival was reduced in radical nephrectomy patients. However, despite reduced renal function in the radical nephrectomy group, non-cancer related death, cardiovascular events, and dialysis were not significantly different between groups. Long-term benefits of partial nephrectomy may be less than previously believed.

\section{Introduction}

Partial nephrectomy is the preferred treatment for localized renal masses because of equivalent cancer control and improved post-operative renal function compared with radical nephrectomy.(1-3) In non-surgical patients, lower renal function is associated with higher cardiovascular events and shorter survival, hence, partial nephrectomy has been considered to be potentially protective against renal failure and future cardiovascular morbidity(4-7) This is supported by cohort studies and a recent systematic review demonstrating lower cardiovascular related events for partial nephrectomy.(8-10),(11) Surprisingly, the only randomized trial of partial versus radical nephrectomy showed that partial nephrectomy resulted in greater mortality.(12) It is possible that the prognostic significance of surgically induced renal function loss differs from a medical renal loss from conditions such as diabetic nephropathy and its association with a higher risk of cardiovascular disease.(5)

Using a large cohort of patients undergoing surgery for renal cell carcinoma (RCC), we examined the association between surgery and mortality, long-term cardiovascular events, and renal related events. We hypothesized that partial nephrectomy versus radical nephrectomy would be associated with reduced mortality owing to fewer cardiovascular complications and reduced need for renal replacement therapy.

\section{Methods}

\section{Study design and setting}

Residents of Ontario, Canada have universal access to hospital care and physician services covered under the Ontario Health Insurance Plan program. These healthcare encounters are recorded in large population-based databases, which are linked using unique, encoded identifiers and held at the ICES (formerly known as the Institute for Clinical Evaluative Sciences). This study was completed through the ICES Kidney, Dialysis and Transplantation research program and all analyses were performed at the ICES Western site in London, Ontario. This study was approved by the University of Western Ontario (\#102933), the Hamilton Integrated (\#14-283-D), and the Ottawa Health Science Network (\#20140446-01H)Research Ethics Boards. We followed the reporting guidelines for observational studies (see Supplementary Table 1).(13) 


\section{Data sources}

Institutional medical record departments identified all partial and radical nephrectomy procedures performed between April 1, 2002 and March 31, 2010 (to ensure a minimum of 5 years follow-up) from three large academic hospitals in Ontario (London Health Sciences Centre, St. Joseph's Healthcare in Hamilton and the Ottawa Hospital). These data were then linked to seven other datasets held at ICES to ascertain information on hospitalizations (Canadian Institute for Health Information's Discharge Abstract Database and Same Day Surgery Database); physician billings for healthcare procedures (Ontario Health Insurance Plan claims database); operating physicians (the ICES Physician database); prescription drug information available only for individuals 66 years and older (Ontario Drug Benefit database); information on patients with end-stage kidney disease or previous kidney transplants (the Ontario portion of the Canadian Organ Replacement Register); vital status information such as birth and death data (Registered Persons Database) and cause of death data from death certificates (Office of the Registrar General).

\section{Patients and exposure status}

Only patients from surgical RCC databases were included in the study

The date of the partial or radical nephrectomy procedure was the index date. Patients were excluded from the study if they had a tumor size larger than seven centimeters (partial nephrectomy is rarely performed for stages higher than Stage 2 RCC), if the surgery date was not between a hospital admission and discharge date (to ascertain hospitalization characteristics and eliminate any recording errors), if patients had evidence of receiving dialysis in the previous year, if they had a kidney transplant, if there was tumor thrombus, or metastatic disease. If patients had more than one nephrectomy during the study period, the first surgery was considered the index procedure.

\section{Outcomes}

Patient outcomes were assessed from index date until end of follow-up, with the latest possible follow-up date of March 31, 2015. Emigration from Ontario is very low (0.1\%/year) and was the only reason for lost study follow-up.(14) The primary outcome was all-cause mortality. The secondary outcomes were hospitalization with a major cardiovascular event (myocardial infarction, stroke, coronary artery bypass surgery, coronary angioplasty), a composite of death or hospitalization with major cardiovascular event, non-cancer related mortality, kidney cancerrelated death, any dialysis, and nephrologist visits. Tertiary outcomes were non-cancer related deaths stratified by pre-operative estimated glomerular filtration rate (eGFR). All analyses were censored for death where relevant.

Pre-specified sub-group analyses for the primary outcome of all-cause mortality were completed for pre-operative eGFR $\left(<45\right.$ versus $\left.\geq 45 \mathrm{~mL} / \mathrm{min} / 1.73 \mathrm{~m}^{2}\right)$ and tumor size $(\leq 4 \mathrm{~cm}$ versus $>4 \mathrm{~cm}$ ) in order to assess whether pre-existing medical renal disease and tumor stage affected the impact of partial versus radical nephrectomy on survival. Post-hoc sub-group 
analyses were also completed for non-cancer related death stratified by pre-operative eGFR and for all-cause mortality stratified by sex. $(4,15-17)$

Post-operative outcomes (in the 30 days following nephrectomy) were serum creatinine and eGFR, length of hospital stay, nephrologist consults, post-operative ICU stay, receipt of dialysis, hospitalizations for major cardiovascular events, and all-cause mortality (Supplementary Table 2).

\section{Baseline characteristics}

Baseline characteristics describing the index surgery were abstracted from the medical record, including date of surgery, surgery site, tumor size based on radiographic measurements, and preoperative serum creatinine, and eGFR - as tumor size and some kidney function measures were not available in ICES data. Information on laparoscopic versus open surgery were obtained from the ICES datasets. Other baseline characteristics obtained from ICES datasets included demographics (patient age, sex, neighbourhood income level based on the census, and rural or urban residence), Johns Hopkins' Adjusted Clinical Group (ACG) scoring system(18) to assess comorbidities based on resource use in the past year, previous visits to a nephrologist, comorbidities or cardiovascular procedures in the five years prior, and prior prescription medications among patients 66 years or older.

\section{Analysis}

All analyses were conducted using SAS version 9.4 (SAS Institute, Cary, NC). Baseline characteristics were compared between partial and radical nephrectomy groups, where a twosided p-value less than 5\% was considered statistically significant with no adjustment for multiple testing. A multivariable logistic regression model including 11 baseline characteristics was used to calculate propensity scores for the probability of receiving a radical versus a partial nephrectomy. These 11 variables were age, sex, tumor size, hospital centre, surgery type, surgery year, pre-operative eGFR, ADG score, previous carotid ultrasound, previous prescription for nitrates, and previous prescription for statins. These characteristics were included either because they were significantly different between the two groups or there was previous evidence of an association with the exposure it was forced into the model. Using this propensity score, we created inverse probability of treatment weights (IPTW) in order for the radical group to better resemble the partial group across the measured baseline characteristics. This 'weighted sample' is essentially a pseudo-sample of people in the radical group who have a similar distribution of baseline characteristics as the partial group. This eliminates some of the potential for confounding based on differences in the characteristics between the two groups, so the associations between groups and the outcomes are less biased, while not excluding any individuals from the analysis.(19) IPTW weights were trimmed at the $1^{\text {st }}$ and $99^{\text {th }}$ percentiles to limit the influence of instable weights.(20)

Hazard ratios were estimated using Cox proportional hazards regression models, accounting for weighting. To test for proportionality we created a time dependent covariate by 
modelling an interaction of procedure type and log-transformed follow-up time. If this time dependent covariate was significant, then the proportionality assumption was considered violated.(21) For outcomes where the proportionality assumption did not hold, the Cox models were time-stratified using Heaviside functions such that the proportionality assumption was met within each time period. Kaplan-Meier curves were generated to visualize differences in survival time between partial and radical nephrectomy groups. As a sensitivity analysis, we repeated analyses using Fine and Gray's model with death as a competing event.

\section{Results}

\section{Baseline characteristics}

There were 2108 nephrectomy procedures abstracted from three academic hospitals, and 1457 patients in the cohort after the exclusion criteria were applied (Supplementary Figure 1). The baseline characteristics between the two groups prior to and after propensity score weighting are presented in Table 1. Prior to weighting, the partial nephrectomy group was younger, more likely to have an open procedure, more likely to have smaller tumors, and had higher pre-operative eGFR. After propensity score weighting, the groups were well-balanced across the measured health characteristics, with the exception of a slightly higher eGFR (81 [20.7] versus 78 [16.9] $\mathrm{mL} / \mathrm{min} / 1.73 \mathrm{~m}^{2}$ ) for the partial compared to the radical group.

\section{Postoperative outcomes}

Peri-operative and post-operative outcomes at 30 days and one year are presented in Table 2. The mean (SD) one-year post-operative eGFR values for the weighted cohort were 71 (22.3) and 52 (13.4) $\mathrm{mL} / \mathrm{min} / 1.73 \mathrm{~m}^{2}$ for the partial and radical groups, respectively $(p<0.0001)$. The proportion of patients who received a nephrology consultation within the year after nephrectomy was $9.4 \%$ for the partial group versus $18.8 \%$ for the radical group $(p<0.0001)$, but the need for chronic dialysis was similar, and very low in both groups (Table 3 ).

\section{Mortality and cardiovascular outcomes}

Patients were followed for a median $\left(25\right.$ th, $75^{\text {th }}$ percentile) of $6.9(5.2,8.5)$ years overall, with a maximum follow-up of 13.8 years (Supplementary Table 3). Patients were followed until mortality or March 31, 2015, whatever date came first. The incidence of all-cause mortality was significantly lower in the partial nephrectomy group compared to the radical nephrectomy group during the first five years of follow-up: 20.4 versus 31.5 deaths per 1000 person-years after weighting (HR $0.42,95 \%$ CI $0.27-0.66, p=0.0001$ ). However, the association was not evident beyond five years (HR 1.01, 95\% CI 0.68-1.49, $p=0.98$ ). The Kaplan-Meier curve showing allcause survival probabilities following partial and radical nephrectomy procedures is presented in Figure 1. Cumulative incidence of all-cause mortality at 1,5 and 9 years is shown in Supplementary Table 4 . There was a significant interaction effect by sex after 5 years or more 
follow-up, where for females, partial versus radical nephrectomy had a protective effect, which was reversed in males (interaction $p=0.0006$ for $5+$ years; Supplementary Figure 2).

Partial (vs. radical) nephrectomy did not associate with a different risk of hospitalization with a major cardiovascular event: 10.2 versus 8.4 events per 1000 person-years in the weighted analysis (HR 1.22, 95\% CI 0.75-1.96, $p=0.43$ ). The incidence of all-cause mortality or major cardiovascular events for the weighted analysis was 29.0 events per 1000 person-years for the partial group and 38.8 events per 1000 person-years for the radical group. This difference was statistically significant in the first four years of follow-up (HR 0.68, 95\% CI 0.48-0.96, $p=0.029$ ) but not after four years (HR 0.97, 95\% 0.67-1.43, $p=0.90$ ). In the weighted analysis, the incidence of non-cancer related deaths was not significantly different between patients in the partial or radical groups (HR 0.88, 95\% CI 0.62-1.25, $p=0.49$; see Figure 2). The incidence of kidney cancer-related mortality was 1.5 and 5.1 events per 1000 person-years for the partial and radical groups, respectively (see Figure 3). This difference was statistically significant in the first four years of follow-up (HR 0.16, 95\% CI 0.04-0.72, $p=0.017$ ) but not beyond 4 years (HR 0.83 (95\% CI 0.20, 3.42), $p=0.80)$.

Pre-operative renal function significantly modified the association of nephrectomy type (partial compared to radical) and all-cause mortality in the first five years of follow-up, with a significant association observed in those with eGFR $\geq 45 \mathrm{~mL} / \mathrm{min} / 1.73 \mathrm{~m}^{2}$ (HR $0.36,95 \%$ CI $0.21-0.62$, interaction $p=0.0025$ ). No significant associations were observed after five years of follow-up, however there was a trend towards higher risk of all-cause mortality for eGFR $<45$ $\mathrm{mL} / \mathrm{min} / 1.73 \mathrm{~m}^{2}$ and lower risk for eGFR $\geq 45 \mathrm{~mL} / \mathrm{min} / 1.73 \mathrm{~m}^{2}$; a significant interaction by preoperative eGFR status was observed $(p<0.0001)$. Importantly, Figure 4 demonstrates that partial nephrectomy does not significantly reduce non-cancer related mortality over radical nephrectomy whether pre-operative eGFR is less than or greater than $45 \mathrm{~mL} / \mathrm{min} / 1.73 \mathrm{~m}^{2}$.

Given that partial nephrectomy patients had smaller tumors on average, we hypothesized that tumor related confounding may explain the association between partial nephrectomy and overall survival. To explore this hypothesis, patients were stratified into tumors $\leq 4 \mathrm{~cm}$ and $>4$ $\mathrm{cm}$. However, no significant interactions were observed when stratified by tumor size (interaction $p=0.32$ for both $<5$ and $5+$ year follow-up intervals; Supplementary Figure 3). The Fine and Gray's model to account for a competing risk of death showed similar results for secondary outcomes (Supplementary Table 5).

\section{Discussion}

Several studies have demonstrated a significant association of cardiovascular events, hospitalization, and even death with the reduction of eGFR in the analyses of large high risk population databases.(5-7) Therefore, despite showing that partial nephrectomy conferred superior renal function compared with radical nephrectomy, we were surprised to show that there was not a difference in the long-term need for dialysis, nor was there a difference in cardiovascular events or non-cancer related mortality between partial and radical nephrectomy 


\section{Effects of renal-preservation surgery on long-term mortality, CV, \& renal outcomes}

groups. However, the aforementioned studies were performed in community-based populations with the majority of patients having medical renal disease as the cause of lower eGFR. Indeed, in our current study, patients with pre-operative eGFR $<45 \mathrm{ml} / \mathrm{min} / 1.73 \mathrm{~m}^{2}$ had inferior all-cause mortality irrespective of operative intervention, illustrating the impact of medical renal disease on overall health. In contrast, healthy patients with significant acute renal loss from nephrectomy (donor nephrectomy), do not have a long-term higher risk of death, cardiovascular events or hospitalization compared with the general population.(22) Although there may be a higher risk of renal replacement therapy long-term, this risk is relatively low.(23) Therefore, there appears to be a distinct difference in the impact of long-standing medical renal disease versus surgical renal loss with regards to general cardiovascular and renal health.

Compared with patients undergoing donor nephrectomy, patients with RCC are older, and have a more significant history of smoking, hypertension, obesity, and diabetes.(24) As well, a number of patients undergoing extirpative surgery for RCC have impaired renal function, with 19\% being classified as stage 3 chronic kidney disease or greater in our population, preoperatively. In fact, we have shown that the presence of diabetes and lower pre-operative eGFR are independent predictors of ongoing long-term renal functional loss in patients undergoing radical nephrectomy.(24) These patients may theoretically be at heightened risk for hyperfiltration injury and accelerated renal loss to end-stage kidney disease. Nevertheless, in this population of patients with coexisting medical renal disease, the impact of the degree of surgical renal loss (radical versus partial nephrectomy) on the acceleration of cardiovascular morbidity and mortality risk was unknown.

For patients with renal tumors, partial nephrectomy has been shown to be associated with better renal function preservation compared to radical nephrectomy, while achieving equivalent oncologic outcomes. $(1,11)$ However, the long-term impact of this renal function preservation has not been established and the only randomized controlled trial (EORTC) revealed worse survival in the partial nephrectomy arm.(12) This study has been criticized for a lengthy and limited patient accrual and it is possible that this study was biased by clinicians accruing patients that were healthier, with superior pre-operative renal function than 'real world' patients with RCC. For the first time, we have shown that although there is a higher proportion of patients with stage 3 chronic kidney disease or greater one year following radical nephrectomy, non-cancer related mortality and cardiovascular events were not different compared to the partial nephrectomy group after a 5-year minimum follow-up. Furthermore, while the proportion of patients requiring nephrology consultation was higher in the radical nephrectomy group, the rate of renal replacement therapy was similarly low in both groups. Even in a subset of patients with stage 3 chronic kidney disease pre-operatively $(\mathrm{eGFR}<45)$, there was no difference in non-cancer related mortality between groups. Another study using the ICES databases found an association between partial nephrectomy and reduced need for dialysis.(25) While that study evaluated all patients in the Ontario, the analysis was limited because of lack of baseline renal function data. 
Unlike the previous EORTC randomized trial comparing partial and radical nephrectomy, we found that cancer-related mortality was higher in the radical nephrectomy group within the first four years of follow-up.(12) This trend persisted even when we analyzed the data in tumors $\leq 4$ $\mathrm{cm}$ and $>4 \mathrm{~cm}$ subsets. This was not explained by a higher early complication rate or mortality ( $<30$ day). We believe that this finding may be the result of residual confounding, despite use of propensity score weighting, with higher risk patients receiving radical nephrectomy. This hypothesis, could not be examined in more detail because we did not capture post-operative tumor type, tumor grade, or tumor stage, all factors associated with cancer prognosis.(26) It is likely that radical nephrectomy was performed in patients with more central tumors or with tumors with a more aggressive radiologic appearance. As central tumors are associated with poorer prognosis, this may explain the inferior oncologic outcomes in the radical nephrectomy group.(27)

In addition to the lack of detailed baseline tumor information, this study should be interpreted with caution because of the lack of long-term reassessment of renal function through the ICES database. While the length of follow-up is longer than most studies in this field, the time to cardiovascular events may be longer than what we were able to observe and the protective effect of partial nephrectomy may emerge with longer follow-up.

\section{Conclusions}

Based on this analysis, the type of extirpative procedure was not associated with non-cancer related mortality, cardiovascular events or renal outcomes. This indicates that the hyperfiltration effect from greater surgical renal loss (radical nephrectomy) may not have the same implications with the progressive effect associated with medical renal disease.

\section{Access to data}

The data set from this study is held securely in coded form at the Institute for Clinical Evaluative Sciences (ICES). While data sharing agreements prohibit ICES from making the data set publicly available, access can be granted to those who meet pre-specified criteria for confidential access, available at www.ices.on.ca/DAS. The full data set creation plan is available from the authors upon request. 


\section{References}

1. MacLennan S, Imamura M, Lapitan MC, Omar MI, Lam TBL, Hilvano-Cabungcal AM, et al. Systematic Review of Oncological Outcomes Following Surgical Management of Localised Renal Cancer. Eur Urol. 2012;61(5):972-93.

2. Ljungberg B, Bensalah K, Canfield S, Dabestani S, Hofmann F, Hora M, et al. EAU Guidelines on Renal Cell Carcinoma: 2014 Update. Vol. 67, European Urology. 2015.

3. Campbell S, Uzzo RG, Allaf ME, Bass EB, Cadeddu JA, Chang A, et al. Renal Mass and Localized Renal Cancer: AUA Guideline. J Urol. 2017 May 4;0(0).

4. Huang WC, Levey AS, Serio AM, Snyder M, Vickers AJ, Raj G V, et al. Chronic kidney disease after nephrectomy in patients with renal cortical tumours: a retrospective cohort study. Lancet Oncol. 2006 Sep;7(9):735-40.

5. Go AS, Chertow GM, Fan D, McCulloch CE, Hsu C. Chronic Kidney Disease and the Risks of Death, Cardiovascular Events, and Hospitalization. N Engl J Med. 2004 Sep 23;351(13):1296-305.

6. Matsushita K, Coresh J, Sang Y, Chalmers J, Fox C, Guallar E, et al. Estimated glomerular filtration rate and albuminuria for prediction of cardiovascular outcomes: a collaborative meta-analysis of individual participant data. Lancet Diabetes Endocrinol. $2015 \mathrm{Jul} ; 3(7): 514-25$.

7. van der Velde M, Matsushita K, Coresh J, Astor BC, Woodward M, Levey AS, et al. Lower estimated glomerular filtration rate and higher albuminuria are associated with allcause and cardiovascular mortality. A collaborative meta-analysis of high-risk population cohorts. Kidney Int. 2011 Jun;79(12):1341-52.

8. Mukkamala A, He C, Weizer AZ, Hafez KS, Miller DC, Montgomery JS, et al. Longterm renal functional outcomes of minimally invasive partial nephrectomy for renal cell carcinoma. Urol Oncol Semin Orig Investig. 2014;32(8):1247-51.

9. Capitanio U, Terrone C, Antonelli A, Minervini A, Volpe A, Furlan M, et al. Nephronsparing Techniques Independently Decrease the Risk of Cardiovascular Events Relative to Radical Nephrectomy in Patients with a T1a-T1b Renal Mass and Normal Preoperative Renal Function. Eur Urol. 2015;67(4):683-9.

10. Weight CJ, Larson BT, Fergany AF, Gao T, Lane BR, Campbell SC, et al. Nephrectomy Induced Chronic Renal Insufficiency is Associated With Increased Risk of Cardiovascular Death and Death From Any Cause in Patients With Localized cT1b Renal Masses. J Urol. 2010;183(4):1317-23.

11. Wang Z, Wang G, Xia Q, Shang Z, Yu X, Wang M, et al. Partial nephrectomy vs. radical nephrectomy for renal tumors: A meta-analysis of renal function and cardiovascular outcomes. Urol Oncol Semin Orig Investig. 2016;34(12):533.e11-533.e19.

12. Van Poppel H, Da Pozzo L, Albrecht W, Matveev V, Bono A, Borkowski A, et al. A Prospective, Randomised EORTC Intergroup Phase 3 Study Comparing the Oncologic Outcome of Elective Nephron-Sparing Surgery and Radical Nephrectomy for Low-Stage Renal Cell Carcinoma. Eur Urol. 2011 Apr;59(4):543-52.

13. Benchimol EI, Smeeth L, Guttmann A, Harron K, Moher D, Petersen I, et al. The REporting of studies Conducted using Observational Routinely-collected health Data 
(RECORD) Statement. PLOS Med. 2015 Oct 6;12(10):e1001885.

14. Ontario Demographic Quarterly: Highlights of fourth quarter, 2018 [Internet]. [cited 2018 Jun 14]. Available from: https://www.fin.gov.on.ca/en/economy/demographics/quarterly/dhiq4.html

15. Thompson RH, Boorjian SA, Lohse CM, Leibovich BC, Kwon ED, Cheville JC, et al. Radical Nephrectomy for pT1a Renal Masses May be Associated With Decreased Overall Survival Compared With Partial Nephrectomy. J Urol. 2008;179(2):468-73.

16. Hafez KS, Fergany AF, Novick AC. Nephron sparing surgery for localized renal cell carcinoma: impact of tumor size on patient survival, tumor recurrence and TNM staging. J Urol. 1999;162(6):1930-3.

17. Fergany AF, Hafez KS, Novick AC. Long-term results of nephron sparing surgery for localized renal cell carcinoma: 10-year followup. J Urol. 2000;163(2):442-5.

18. Weiner, JP. Abrams, C. Bodycombe D. The Johns Hopkins ACG ${ }^{\circledR}$ Case-Mix System Version 10.0 Release Notes. 2011;

19. Austin PC. An Introduction to Propensity Score Methods for Reducing the Effects of Confounding in Observational Studies. Multivariate Behav Res. 2011 May 31;46(3):399424.

20. Lee BK, Lessler J, Stuart EA. Weight trimming and propensity score weighting. PLoS One. 2011 Mar 31;6(3):e18174.

21. NG'ANDU NH. AN EMPIRICAL COMPARISON OF STATISTICAL TESTS FOR ASSESSING THE PROPORTIONAL HAZARDS ASSUMPTION OF COX'S MODEL. Stat Med. 1997 Mar 30;16(6):611-26.

22. Garg AX, Meirambayeva A, Huang A, Kim J, Prasad GVR, Knoll G, et al. Cardiovascular disease in kidney donors: matched cohort study. BMJ. 2012;344.

23. Segev DL, Muzaale AD, Caffo BS, Mehta SH, Singer AL, Taranto SE, et al. Perioperative Mortality and Long-term Survival Following Live Kidney Donation. JAMA. 2010 Mar 10;303(10):959.

24. Mamut AE, Violette PD, Rowe NE, Cui F, Luke PP. Measuring the Impact of Medical Chronic Kidney Disease and Diabetes Mellitus on Renal Functional Decline Following Surgical Management of Renal Masses. Urology. 2016;91:124-8.

25. Yap SA, Finelli A, Urbach DR, Tomlinson GA, Alibhai SMH. Partial nephrectomy for the treatment of renal cell carcinoma $(\mathrm{RCC})$ and the risk of end-stage renal disease (ESRD). BJU Int. 2015 Jun;115(6):897-906.

26. Parker WP, Cheville JC, Frank I, Zaid HB, Lohse CM, Boorjian SA, et al. Application of the Stage, Size, Grade, and Necrosis (SSIGN) Score for Clear Cell Renal Cell Carcinoma in Contemporary Patients. Eur Urol. 2017;71(4):665-73.

27. Correa AF, Toussi A, Amin M, Hrebinko RL, Gayed BA, Parwani A V., et al. Small Renal Masses in Close Proximity to the Collecting System and Renal Sinus Are Enriched for Malignancy and High Fuhrman Grade and Should Be Considered for Early Intervention. Clin Genitourin Cancer. 2018 Aug 1;16(4):e729-33.

28. Yap SA, Alibhai SMH, Margel D, Abouassaly R, Timilshina N, Finelli A. A populationbased study of surgeon characteristics associated with the uptake of contemporary techniques in renal surgery. Can Urol Assoc J. 2013;7(9-10):E576-81. 


\section{Figures and Tables}

Fig. 1. Kaplan-Meier curve of survival time following partial and radical procedures. CI: confidence interval; HR: hazard ratio.

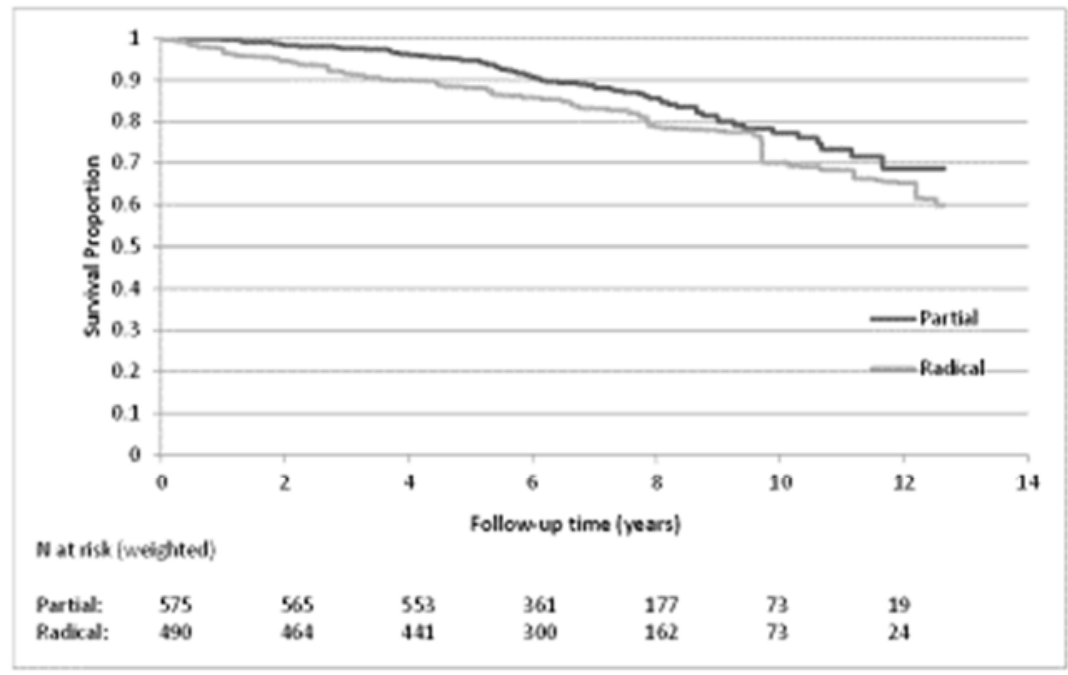

\footnotetext{
Time-stratified proportional hazard ratios (HR) and p-values for partial compared to radical (referent groupl:

$0 .<5$ years: $\operatorname{HR}(95 \% \mathrm{CI}): 0.42(0.27,0.66), \rho=0.0001$

5+ years: $H R(95 \% \mathrm{CI}): 1.01(0.68,1.49), 0=0.98$
}

Fig. 2. Kaplan-Meier curve of non-cancer-related survival time following partial and radical procedures. CI: confidence interval; HR: hazard ratio.

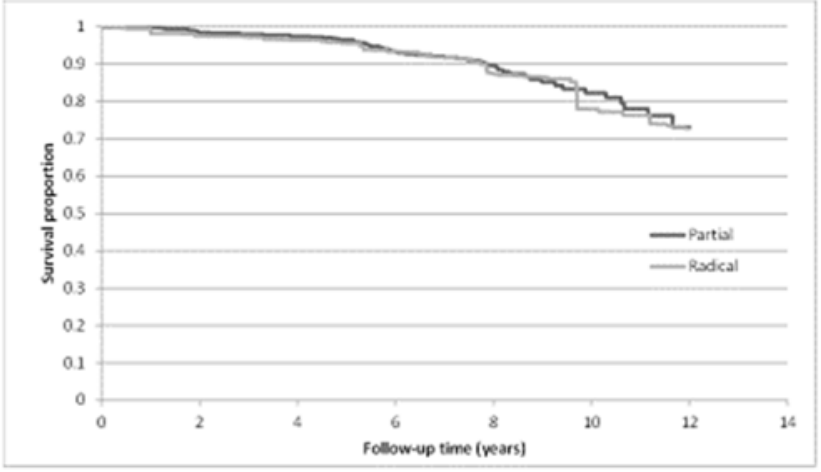

Proportional harard ratios (MR) and p-values for partial compared to radical (referent group):

HR $(95 \% \mathrm{Cl}): 0.88(0.62,1.25), p=0.49$ 
Fig. 3. Kaplan-Meier curve of kidney cancer-related survival time partial and radical procedures. CI: confidence interval; HR: hazard ratio.

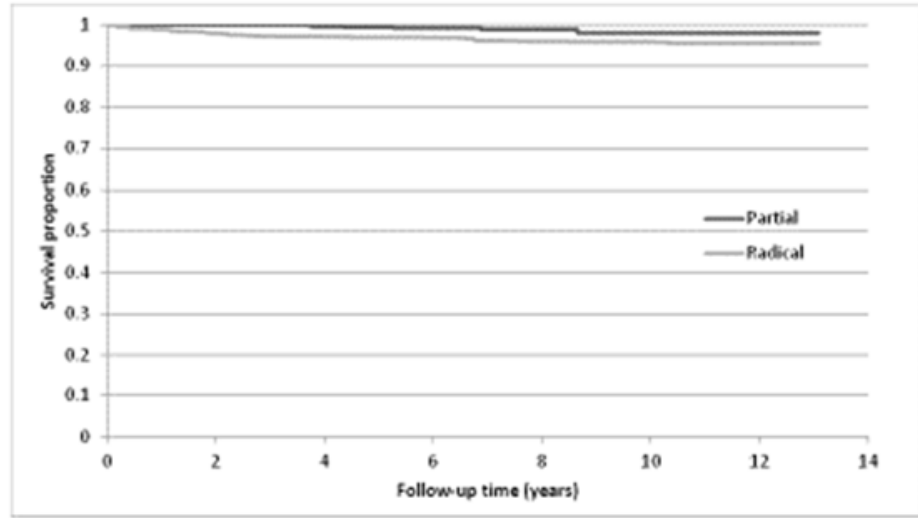

Time-stratified proportional harard ratios (MR) and p-values for partial compared to radical (referent group):

$0-<4$ years: $H R(95 \% \mathrm{Cl}): 0.16(0.04,0.72), p=0.0169$

$4+$ vears: $H R(95 \% \mathrm{Cl}): 0.83(95 \% \mathrm{Cl} 0.20,3.42), p=0.80$

Fig. 4. Kaplan-Meier curve of non-cancer-related survival in patients stratified by preoperative estimated glomerular filtration rate (eGFR). CI: confidence interval; HR: hazard ratio.

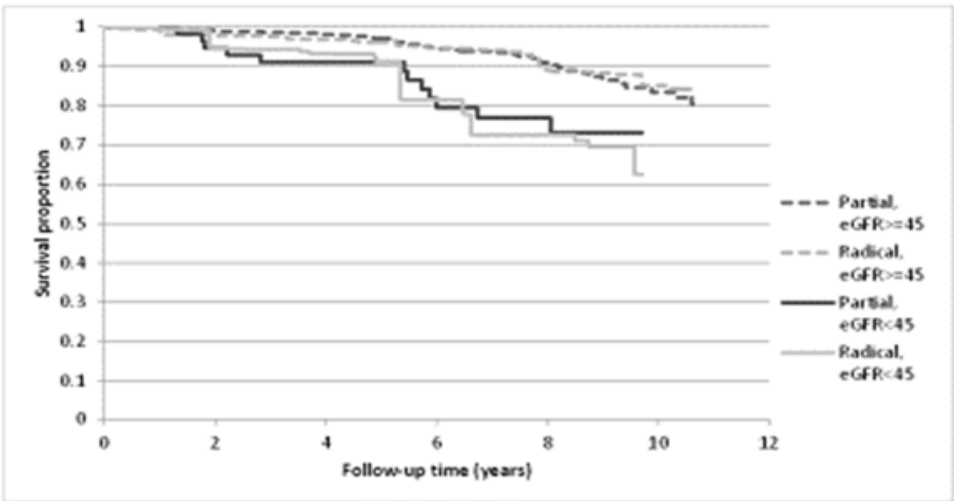

For GFR 45 Proportional harard ratios (MR) and 95\% confidence intervals (CI) for partial compared to radical (referent group): $M R$ (95\% a): $0.65(0.37,1.15)$

For GFR $\geq 45$ Proportional hazard ratios (HR) and 95\% confidence intervals (CI) for partial compared to radical (referent group): $\operatorname{KR}(95 \%$ a): $0.99(0.66,1.49)$ interaction p-value: $<0.0001$. 
Effects of renal-preservation surgery on long-term mortality, CV, \& renal outcomes

\begin{tabular}{|c|c|c|c|c|c|c|}
\hline \multirow[b]{2}{*}{ Characteristic } & \multicolumn{3}{|c|}{ Pre-weighting } & \multicolumn{3}{|c|}{ Post-weighting } \\
\hline & $\begin{array}{l}\text { Partial } \\
n=575\end{array}$ & $\begin{array}{c}\text { Radical } \\
\mathrm{n}=\mathbf{8 8 2}\end{array}$ & $\mathbf{p}^{1}$ & $\begin{array}{c}\text { Partial } \\
\mathbf{n}=\mathbf{5 7 5}\end{array}$ & $\begin{array}{c}\text { Radical } \\
\mathrm{n}=490^{2}\end{array}$ & $\mathbf{p}^{1}$ \\
\hline \multicolumn{7}{|l|}{ Demographics } \\
\hline Age, years (mean, SD) & $59(12.45)$ & $62(12.41)$ & $<0.001$ & $59(12.45)$ & $59(9.82)$ & 0.84 \\
\hline Range & $21-85$ & $19-92$ & 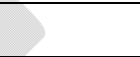 & $21-85$ & $19-92$ & \\
\hline Women & $37.9 \%$ & $41.7 \%$ & 0.15 & $37.9 \%$ & $39.5 \%$ & 0.59 \\
\hline \multicolumn{7}{|l|}{ Income quintile ${ }^{3}$} \\
\hline 1 (lowest) & $17.2 \%$ & $18.7 \%$ & 0.28 & $17.2 \%$ & $16.2 \%$ & 0.78 \\
\hline 2 & $18.1 \%$ & $20.9 \%$ & 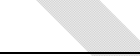 & $18.1 \%$ & $20.2 \%$ & \\
\hline 3 & $22.3 \%$ & $19.0 \%$ & & $22.3 \%$ & $20.2 \%$ & \\
\hline 4 & $19.8 \%$ & $20.7 \%$ & & $19.8 \%$ & $19.6 \%$ & \\
\hline 5 (highest) & $22.6 \%$ & $20.6 \%$ & 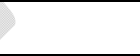 & $22.6 \%$ & $23.7 \%$ & \\
\hline Rural $^{4}$ & $18.4 \%$ & $15.1 \%$ & 0.09 & $18.4 \%$ & $16.4 \%$ & 0.39 \\
\hline \multicolumn{7}{|l|}{ Index surgery characteristics } \\
\hline \multicolumn{7}{|l|}{ Surgery site } \\
\hline London & $28.5 \%$ & $20.4 \%$ & $<0.001$ & $28.5 \%$ & $26.9 \%$ & 0.63 \\
\hline Ottawa & $43.1 \%$ & $38.8 \%$ & & $43.1 \%$ & $42.1 \%$ & \\
\hline Hamilton & $28.3 \%$ & $40.8 \%$ & & $28.3 \%$ & $31.0 \%$ & \\
\hline \multicolumn{7}{|l|}{ Surgery type } \\
\hline Laparoscopic & $37.9 \%$ & $54.6 \%$ & $<0.001$ & $37.9 \%$ & $39.7 \%$ & 0.59 \\
\hline Open & $49.0 \%$ & $34.4 \%$ & & $49.0 \%$ & $46.0 \%$ & \\
\hline Missing & $13.0 \%$ & $11.0 \%$ & & $13.0 \%$ & $14.3 \%$ & \\
\hline \multicolumn{7}{|l|}{ Tumor Size } \\
\hline$\leq 1 \mathrm{~cm}$ & $10.1 \%$ & $1.5 \%$ & $<0.001$ & $10.1 \%$ & $9.5 \%$ & 0.67 \\
\hline $2 \mathrm{~cm}$ & $37.0 \%$ & $7.7 \%$ & & $37.0 \%$ & $31.4 \%$ & \\
\hline $3 \mathrm{~cm}$ & $30.4 \%$ & $21.0 \%$ & & $30.4 \%$ & $32.8 \%$ & \\
\hline $4 \mathrm{~cm}$ & $14.6 \%$ & $22.6 \%$ & & $14.6 \%$ & $17.2 \%$ & \\
\hline $5 \mathrm{~cm}$ & $3.8 \%$ & $20.7 \%$ & & $3.8 \%$ & $4.6 \%$ & \\
\hline $6 \mathrm{~cm}$ & $2.4 \%$ & $15.2 \%$ & & $2.4 \%$ & $2.6 \%$ & \\
\hline $7 \mathrm{~cm}$ & $1.6 \%$ & $11.3 \%$ & & $1.6 \%$ & $2.0 \%$ & \\
\hline \multicolumn{7}{|l|}{ Surgery year } \\
\hline $2001-2005$ & $22.80 \%$ & $39.70 \%$ & $<0.001$ & $22.80 \%$ & $26.60 \%$ & 0.33 \\
\hline $2006-2010$ & $77.30 \%$ & $60.30 \%$ & & $77.30 \%$ & $73.40 \%$ & \\
\hline \multicolumn{7}{|l|}{ Preoperative kidney function } \\
\hline Serum creatinine $(\text { mean, } \mathrm{SD})^{5}$ & $86(27)$ & $87(31)$ & 0.54 & $86(27)$ & $91(32)$ & 0.011 \\
\hline
\end{tabular}


Effects of renal-preservation surgery on long-term mortality, CV, \& renal outcomes

\begin{tabular}{|c|c|c|c|c|c|c|}
\hline $\begin{array}{l}\text { eGFR, } \mathrm{mL} / \mathrm{min} \text { per } 1.73 \mathrm{~m}^{2} \\
(\mathrm{mean}, \mathrm{SD})^{6}\end{array}$ & $81(20)$ & $77(20)$ & 0.003 & $81(20)$ & $78(16)$ & 0.035 \\
\hline$\geq 60$ & $80.2 \%$ & $76.8 \%$ & \multirow[t]{5}{*}{0.10} & $80.2 \%$ & $77.0 \%$ & \multirow[t]{5}{*}{0.71} \\
\hline $45-<60$ & $9.9 \%$ & $13.9 \%$ & & $9.9 \%$ & $10.9 \%$ & \\
\hline $30-<45$ & $5.9 \%$ & $4.3 \%$ & & $5.9 \%$ & $6.9 \%$ & \\
\hline$<30$ & $1.2 \%$ & $1.6 \%$ & & $1.2 \%$ & $2.0 \%$ & \\
\hline Missing & $2.8 \%$ & $3.4 \%$ & & $2.8 \%$ & $3.2 \%$ & \\
\hline $\begin{array}{l}\text { Number of days between } \\
\text { preoperative test and index } \\
\text { date }\end{array}$ & $12(35.10)$ & $13(44.46)$ & 0.58 & $12(35.1)$ & $13(23.26)$ & 0.76 \\
\hline \multicolumn{7}{|l|}{ Comorbidities $^{7}$} \\
\hline $\begin{array}{l}\text { Stroke/transient ischemic } \\
\text { attack }\end{array}$ & $0.9 \%$ & $1.1 \%$ & 0.63 & $0.9 \%$ & $0.4 \%$ & 0.39 \\
\hline Peripheral vascular disease & $0.9 \%$ & $1.6 \%$ & 0.24 & $0.9 \%$ & $1.3 \%$ & 0.46 \\
\hline Coronary artery disease & $24.9 \%$ & $26.9 \%$ & 0.40 & $24.9 \%$ & $24.4 \%$ & 0.85 \\
\hline Myocardial infarction & $3.0 \%$ & $2.9 \%$ & 0.99 & $3.0 \%$ & $1.8 \%$ & 0.21 \\
\hline Diabetes & $23.7 \%$ & $23.1 \%$ & 0.82 & $23.7 \%$ & $20.4 \%$ & 0.20 \\
\hline Hypertension & $60.0 \%$ & $62.2 \%$ & 0.39 & $60.0 \%$ & $60.8 \%$ & 0.79 \\
\hline Carotid ultrasound & $6.6 \%$ & $9.9 \%$ & 0.03 & $6.6 \%$ & $8.5 \%$ & 0.24 \\
\hline Coronary angiogram & $7.8 \%$ & $7.5 \%$ & 0.81 & $7.8 \%$ & $6.8 \%$ & 0.52 \\
\hline Coronary revascularization & $4.5 \%$ & $3.6 \%$ & 0.39 & $4.5 \%$ & $2.9 \%$ & 0.18 \\
\hline Echocardiography & $30.3 \%$ & $30.3 \%$ & 1.00 & $30.3 \%$ & $28.6 \%$ & 0.56 \\
\hline Holter monitor & $13.2 \%$ & $12.1 \%$ & 0.54 & $13.2 \%$ & $10.6 \%$ & 0.19 \\
\hline Stress test & $40.7 \%$ & $42.5 \%$ & 0.49 & $40.7 \%$ & $44.4 \%$ & 0.22 \\
\hline $\begin{array}{l}\text { Nephrology consult (at least } \\
\text { one) }\end{array}$ & $7.8 \%$ & $6.0 \%$ & 0.18 & $7.8 \%$ & $7.9 \%$ & 0.98 \\
\hline $\begin{array}{l}\text { Johns Hopkins' ADG score in } \\
\text { past } 1 \text { year (mean, SD) }\end{array}$ & $7(2.89)$ & $7(2.78)$ & 0.34 & $7(2.89)$ & $7(2.17)$ & 0.97 \\
\hline $0-4$ & $17.9 \%$ & $16.3 \%$ & & $17.9 \%$ & $18.7 \%$ & \\
\hline $5-9$ & $62.8 \%$ & $62.7 \%$ & & $62.8 \%$ & $62.2 \%$ & \\
\hline $10--14$ & $17.2 \%$ & $20.2 \%$ & & $17.2 \%$ & $18.1 \%$ & \\
\hline $15+$ & $2.1 \%$ & $0.8 \%$ & & $2.1 \%$ & $1.0 \%$ & \\
\hline \multicolumn{7}{|c|}{ Medications in the past 120 days from index date (for subset $>66$ years) ${ }^{8}$} \\
\hline Age $\geq 66$ years & $34.4 \%$ & $41.2 \%$ & 0.01 & $34.4 \%$ & $32.6 \%$ & 0.53 \\
\hline Diabetes drugs & $16.7 \%$ & $14.6 \%$ & 0.52 & $16.7 \%$ & $16.0 \%$ & 0.82 \\
\hline ACE inhibitors & $40.9 \%$ & $40.2 \%$ & 0.87 & $40.9 \%$ & $44.4 \%$ & 0.51 \\
\hline ARBs & $16.2 \%$ & $13.8 \%$ & 0.44 & $16.2 \%$ & $14.4 \%$ & 0.69 \\
\hline Statins & $46.0 \%$ & $36.9 \%$ & 0.04 & $46.0 \%$ & $41.9 \%$ & 0.42 \\
\hline Nitrates & $4.0 \%$ & $7.7 \%$ & 0.09 & $4.0 \%$ & $6.3 \%$ & 0.34 \\
\hline
\end{tabular}


Effects of renal-preservation surgery on long-term mortality, CV, \& renal outcomes

\begin{tabular}{|l|l|l|l|l|l|l|}
\hline Any anti-hypertensive drug & $70.7 \%$ & $73.6 \%$ & 0.47 & $70.7 \%$ & $74.4 \%$ & 0.43 \\
\hline \multicolumn{2}{|l|}{} \\
\hline
\end{tabular}

${ }^{1} \mathrm{P}$-values were calculated using Student's t-test for continuous variables and the chi-squared test for binary and categorical variables. ${ }^{2}$ After weighing, the frequency/sample size in the radical group was $490 .{ }^{3}$ Missing income inputted into income quintile $3 .{ }^{4} \mathrm{~A}$ rural location is defined as populations $<10000 .{ }^{5}$ The mean time between the baseline serum creatinine measurement date and the surgery date was 12 for the group and 13 for the group, which did not change after propensity weighting. ${ }^{6}$ GFR was calculated using the Chronic Kidney Disease Epidemiology Collaboration (CKD-EPI) equation; all patients were assumed to be non-black in the CKD-EPI equation, given the lack of data for race (a reasonable assumption since less than $5 \%$ of the Ontario population is of black race). ${ }^{7}$ All comorbidities were assessed in the past 5 years from the surgery date. ${ }^{8}$ Percentages calculated from participants $>66$ years only, as this is the segment of the population that has universal drug benefits. ACE: angiotensin-converting enzyme; ADG: aggregated diagnostic group; ARB: angiotensin receptor blocker; eGFR: estimated glomerular filtration rate; SD: standard deviation.

\begin{tabular}{|c|c|c|c|}
\hline \multirow{2}{*}{$\begin{array}{l}\text { Outcome } \\
\text { Perioperative outcomes }\end{array}$} & $\begin{array}{l}\text { Partia } \\
\mathbf{n}=\mathbf{5 7 5}\end{array}$ & $\begin{array}{l}\text { Radical } \\
\mathrm{n}=490^{1}\end{array}$ & \multirow[t]{2}{*}{ p } \\
\hline & 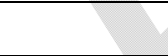 & 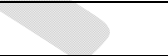 & \\
\hline $\begin{array}{l}\text { Hospital length of stay, days } \\
\text { (mean, SD) }\end{array}$ & $\begin{array}{c}4.66 \\
(2.38) \\
\end{array}$ & $\begin{array}{c}4.73 \\
(3.01) \\
\end{array}$ & 0.66 \\
\hline Median, IQR & $4(3-5)$ & $4(3-5)$ & \\
\hline Intensive care unit visit & $\begin{array}{c}12 \\
(2.1 \%)\end{array}$ & $\begin{array}{c}24.2 \\
(4.9 \%)\end{array}$ & 0.0104 \\
\hline $\begin{array}{l}\text { Mechanical ventilation in the } \\
\text { intensive care unit }\end{array}$ & $\begin{array}{c}<6 \\
(<1.0 \%) \\
\end{array}$ & $\begin{array}{c}15.1 \\
(3.1 \%)\end{array}$ & 0.0001 \\
\hline \multicolumn{4}{|l|}{ Postoperative 30-day outcomes } \\
\hline Stroke/ transient ischemic attack & $\begin{array}{c}0 \\
(0.0 \%) \\
\end{array}$ & $\begin{array}{c}<6 \\
(<1.2 \%)\end{array}$ & \\
\hline Peripheral vascular disease & $\begin{array}{c}<6 \\
(<1.0 \%)\end{array}$ & $\begin{array}{c}<6 \\
(<1.2 \%)\end{array}$ & \\
\hline Coronary artery disease & $\begin{array}{c}58 \\
(10.1 \%) \\
\end{array}$ & $\begin{array}{c}41.3 \\
(8.4 \%) \\
\end{array}$ & 0.35 \\
\hline Myocardial infarction & $\begin{array}{c}<6 \\
(<1.0 \%)\end{array}$ & $\begin{array}{c}<6 \\
(<1.2 \%)\end{array}$ & \\
\hline \multicolumn{4}{|l|}{ Postoperative 1-year outcomes } \\
\hline $\mathrm{eGFR}, \mathrm{mL} / \mathrm{min}$ per $1.73 \mathrm{~m}^{2}$ & & & \\
\hline
\end{tabular}


Effects of renal-preservation surgery on long-term mortality, CV, \& renal outcomes

\begin{tabular}{|c|c|c|c|}
\hline Mean (SD) & $\begin{array}{c}71 \\
(22.35)\end{array}$ & $\begin{array}{c}52 \\
(13.40)\end{array}$ & $<0.0001$ \\
\hline Median (IQR) & $\begin{array}{c}71 \\
(57-88)\end{array}$ & $\begin{array}{c}51 \\
(41-63)\end{array}$ & \\
\hline Normal/ Stage 1-2 & $\begin{array}{c}196 \\
(34.1 \%)\end{array}$ & $\begin{array}{c}76.1 \\
(15.5 \%)\end{array}$ & \\
\hline Stage $3 a$ & $\begin{array}{c}36 \\
(6.3 \%)\end{array}$ & $\begin{array}{c}70.2 \\
(14.3 \%)\end{array}$ & \\
\hline Stage $3 b$ & $\begin{array}{c}24 \\
(4.2 \%) \\
\end{array}$ & $\begin{array}{c}64.8 \\
(13.2 \%) \\
\end{array}$ & \\
\hline Stage $4-5$ & $\begin{array}{c}14 \\
(2.4 \%)\end{array}$ & $\begin{array}{c}24.3 \\
(5.0 \%) \\
\end{array}$ & \\
\hline Missing & $\begin{array}{c}305 \\
(53.0 \%) \\
\end{array}$ & $\begin{array}{c}255.1 \\
(52.0 \%) \\
\end{array}$ & \\
\hline Nephrologist consult (at least one) & $\begin{array}{c}54 \\
(9.4 \%) \\
\end{array}$ & $\begin{array}{c}92.0 \\
(18.8 \%)\end{array}$ & $<0.0001$ \\
\hline Stroke/transient ischemic attack & $\begin{array}{c}<6 \\
(<1.0 \%)\end{array}$ & $\begin{array}{c}<6 \\
(<1.2 \%)\end{array}$ & \\
\hline Peripheral vascular disease & $\begin{array}{c}<6 \\
(<1.0 \%)\end{array}$ & $\begin{array}{c}<6 \\
(<1.2 \%)\end{array}$ & \\
\hline Coronary artery disease & $\begin{array}{c}88 \\
(15.3 \%) \\
\end{array}$ & $\begin{array}{c}76.65 \\
(15.6 \%) \\
\end{array}$ & 0.88 \\
\hline Myocardial infarction & $\begin{array}{c}<6 \\
(<1.0 \%)\end{array}$ & $\begin{array}{c}<6 \\
(<1.2 \%) \\
\end{array}$ & \\
\hline
\end{tabular}

Note: Data presented as number (percent) unless otherwise noted; cell sizes $<6$ have been suppressed in accordance with ICES privacy policies. ${ }^{1}$ After weighing, the frequency/ sample size in the radical group was 490. eGFR: estimated glomerular filtration rate; IQR: interquartile range; SD: standard deviation. 


\begin{tabular}{|c|c|c|c|c|}
\hline Outcome & Exposure & $\begin{array}{c}\text { Incidence } \\
\text { rate per } \\
1000 \\
\text { person } \\
\text { years }\end{array}$ & \multicolumn{2}{|c|}{$\begin{array}{c}\text { Hazard ratio } \\
\text { (95\% confidence interval) }\end{array}$} \\
\hline \multirow[b]{3}{*}{ All-cause mortality } & \multirow{3}{*}{$\begin{array}{l}\text { Partial } \\
\text { Radical }\end{array}$} & \multirow{3}{*}{20.4} & $0-<5$ years & $5+$ years \\
\hline & & & $0.42(0.27,0.66)$ & $1.01(0.68,1.49)$ \\
\hline & & & 1.00 (referent) & 1.00 (referent) \\
\hline $\begin{array}{l}\text { with major } \\
\text { cardiovascular } \\
\text { event }\end{array}$ & $\begin{array}{l}\text { Partial } \\
\text { Radical }\end{array}$ & $\begin{array}{c}10.2 \\
8.4\end{array}$ & $\begin{array}{r}\text { Total follo } \\
1.22(0 \\
1.00\end{array}$ & $\begin{array}{l}\text { up period } \\
5,1.96) \\
\text { erent) }\end{array}$ \\
\hline \multirow{3}{*}{$\begin{array}{l}\text { All-cause mortality } \\
\text { or cardiovascular } \\
\text { disease }\end{array}$} & \multirow{3}{*}{$\begin{array}{l}\text { Partial } \\
\text { Radical }\end{array}$} & \multirow{3}{*}{$\begin{array}{l}29.0 \\
38.8\end{array}$} & $0-<4$ years & $4+$ years \\
\hline & & & $0.68(0.48,0.96)$ & $0.97(0.67,1.43)$ \\
\hline & & & 1.00 (referent) & 1.00 (referent) \\
\hline $\begin{array}{l}\text { Non-cancer related } \\
\text { mortality }\end{array}$ & $\begin{array}{l}\text { Partial } \\
\text { Radical }\end{array}$ & $\begin{array}{l}15.2 \\
18.7 \\
\end{array}$ & \multicolumn{2}{|c|}{$\begin{array}{c}\text { Total followup period } \\
0.88(0.62,1.25) \\
1.00 \text { (referent) } \\
\end{array}$} \\
\hline \multirow{3}{*}{$\begin{array}{l}\text { Kidney cancer- } \\
\text { related mortality }\end{array}$} & \multirow{3}{*}{$\begin{array}{l}\text { Partial } \\
\text { Radical }\end{array}$} & \multirow{3}{*}{$\begin{array}{l}1.5 \\
5.1 \\
\end{array}$} & $0-<4$ years & $4+$ years \\
\hline & & & $0.16(0.04,0.72)$ & $0.83(0.20,3.42)$ \\
\hline & & & 1.00 (referent) & 1.00 (referent) \\
\hline $\begin{array}{l}\text { Any dialysis (acute } \\
\text { or chronic) }\end{array}$ & $\begin{array}{c}\text { Partial } \\
\text { Radical }\end{array}$ & $\begin{array}{l}3.5 \\
2.8 \\
\end{array}$ & \multicolumn{2}{|c|}{$\begin{array}{c}\text { Total followup period } \\
1.27(0.56,2.86) \\
1.00 \text { (referent) }\end{array}$} \\
\hline Nephrologist visit & $\begin{array}{l}\text { Partial } \\
\text { Radical }\end{array}$ & $\begin{array}{l}28.7 \\
78.2\end{array}$ & $\begin{array}{r}\text { Total follo } \\
0.40(0 \\
1.00 \\
\end{array}$ & $\begin{array}{l}\text { up period } \\
(, 0.51) \\
\text { erent) }\end{array}$ \\
\hline
\end{tabular}

For outcomes where the proportionality assumption did not hold, the Cox models were timestratified such that the proportionality assumption was met within each time period (at 4 or 5 years). 
Supplementary Fig. 1. Participant flow diagram.

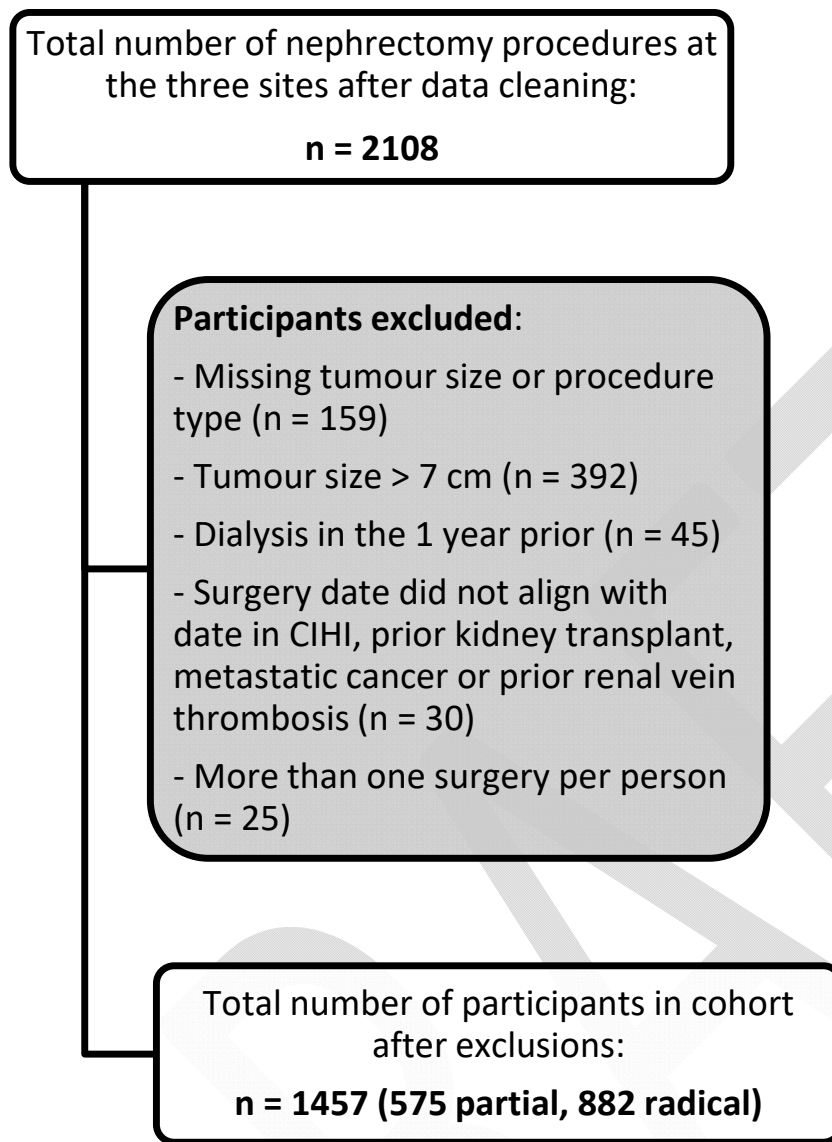


Supplementary Fig. 2. Kaplan-Meier curve of survival time following partial and radical procedures stratified by sex.

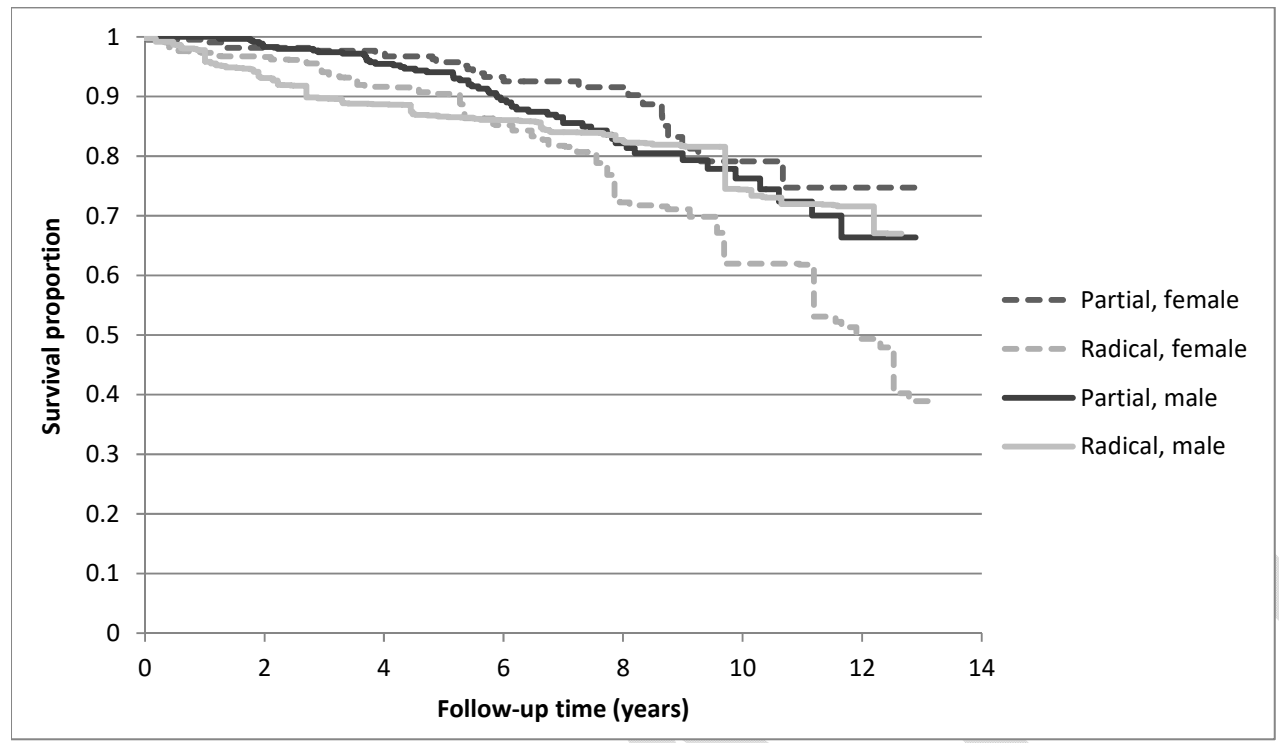

Time-stratified proportional hazard ratios (HR) and 95\% confidence interval (CI) for partial compared to radical (referent group) among females:

$0-<5$ years: $\mathrm{HR}(95 \% \mathrm{CI}): 0.42(0.19,0.94)$

5+ years: HR $(95 \% \mathrm{CI}): 0.44(0.23,0.84)$

Time-stratified proportional hazard ratios (HR) and 95\% confidence interval (CI) for partial compared to radical (referent group) among males:

$0-<5$ years: $\mathrm{HR}(95 \% \mathrm{CI}): 0.42(0.25,0.71)$

5+ years: HR (95\% CI): $1.69(1.00,2.85)$

Interaction $p$-values:

$0-<5$ years: 0.96

5+ years: 0.0006 
Supplementary Fig. 3. Kaplan-Meier curve of survival time following partial and radical procedures stratified by tumor size.

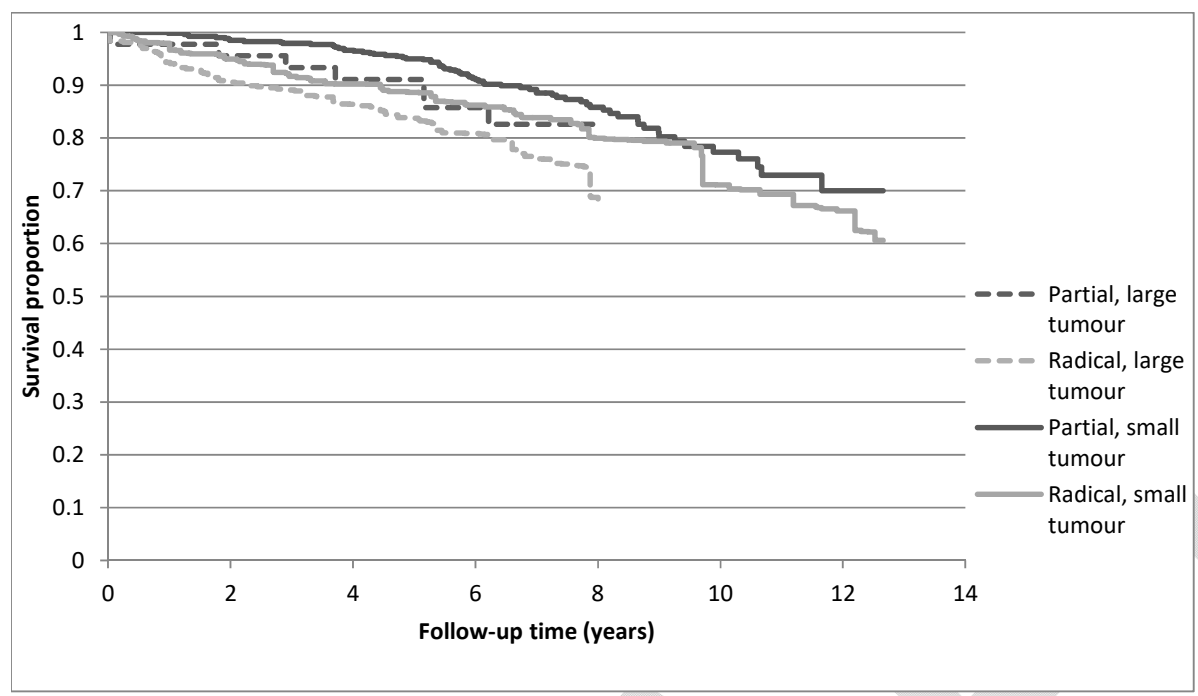

Time-stratified proportional hazard ratios (HR) and 95\% confidence interval (CI) for partial compared to radical (referent group) among patients with tumor $\leq 4 \mathrm{~cm}$ :

$0-<5$ years: HR $(95 \% \mathrm{CI}): 0.41(0.26,0.66)$

5+ years: HR $(95 \% \mathrm{CI}): 1.02(0.68,1.54)$

Time-stratified proportional hazard ratios (HR) and 95\% confidence interval (CI) for partial compared to radical (referent group) among patients with tumor $>4 \mathrm{~cm}$ :

$0-<5$ years: HR $(95 \% \mathrm{CI}): 0.53(0.16,1.79)$

5+ years: HR $(95 \% \mathrm{CI}): 0.85(0.25,2.86)$

Interaction $p$-values:

$0-<5$ years: 0.32

5+ years: 0.32 


\section{Supplementary Table 1: REporting of studies Conducted using Observational Routinely-collected health Data (RECORD) Statement}

\begin{tabular}{|c|c|c|c|c|}
\hline & $\begin{array}{c}\text { Item } \\
\text { no }\end{array}$ & STROBE items & RECORD items & Reported \\
\hline Title and abstract & 1 & $\begin{array}{l}\text { (a) Indicate the study's design } \\
\text { with a commonly used term } \\
\text { in the title or the abstract. } \\
\text { (b) Provide in the abstract an } \\
\text { informative and balanced } \\
\text { summary of what was done } \\
\text { and what was found. }\end{array}$ & $\begin{array}{l}\text { (1.1) The type of data used } \\
\text { should be specified in the } \\
\text { title or abstract. When } \\
\text { possible, the name of the } \\
\text { databases used should be } \\
\text { included. } \\
\text { (1.2) If applicable, the } \\
\text { geographic region and time } \\
\text { frame within which the } \\
\text { study took place should be } \\
\text { reported in the title or } \\
\text { abstract. } \\
\text { (1.3) If linkage between } \\
\text { databases was conducted } \\
\text { for the study, this should be } \\
\text { clearly stated in the title or } \\
\text { abstract. }\end{array}$ & Title and Abstract \\
\hline \multicolumn{5}{|l|}{ Introduction } \\
\hline $\begin{array}{l}\text { Background/ } \\
\text { rationale }\end{array}$ & 2 & $\begin{array}{c}\text { Explain the scientific } \\
\text { background and rationale for } \\
\text { the investigation being } \\
\text { reported. }\end{array}$ & & Introduction \\
\hline Objectives & 3 & $\begin{array}{c}\text { State specific objectives, } \\
\text { including any prespecified } \\
\text { hypotheses. }\end{array}$ & & Introduction \\
\hline \multicolumn{5}{|l|}{ Methods } \\
\hline Study design & 4 & $\begin{array}{l}\text { Present key elements of study } \\
\text { design early in the paper. }\end{array}$ & & $\begin{array}{l}\text { Study design and } \\
\text { setting }\end{array}$ \\
\hline Setting & 5 & $\begin{array}{l}\text { Describe the setting, } \\
\text { locations, and relevant dates, } \\
\text { including periods of } \\
\text { recruitment, exposure, } \\
\text { follow-up, and data } \\
\text { collection. }\end{array}$ & & $\begin{array}{l}\text { Study design and } \\
\text { setting \& data } \\
\text { sources }\end{array}$ \\
\hline Participants & 6 & $\begin{array}{l}\text { (a) Give the eligibility } \\
\text { criteria, and the sources and } \\
\text { methods of selection of }\end{array}$ & $\begin{array}{l}\text { (6.1) The methods of study } \\
\text { population selection (such } \\
\text { as codes or algorithms used }\end{array}$ & $\begin{array}{l}\text { Data sources \& } \\
\text { patients and } \\
\text { exposure status }\end{array}$ \\
\hline
\end{tabular}




\begin{tabular}{|c|c|c|c|c|}
\hline & & $\begin{array}{l}\text { participants. Describe } \\
\text { methods of follow-up. } \\
\text { (b) For matched studies, give } \\
\text { matching criteria and number } \\
\text { of exposed and unexposed. }\end{array}$ & $\begin{array}{l}\text { to identify subjects) should } \\
\text { be listed in detail. If this is } \\
\text { not possible, an } \\
\text { explanation should be } \\
\text { provided. } \\
\text { (6.2) Any validation studies } \\
\text { of the codes or algorithms } \\
\text { used to select the } \\
\text { population should be } \\
\text { referenced. If validation } \\
\text { was conducted for this } \\
\text { study and not published } \\
\text { elsewhere, detailed } \\
\text { methods and results should } \\
\text { be provided. } \\
\text { (6.3) If the study involved } \\
\text { linkage of databases, } \\
\text { consider use of a flow } \\
\text { diagram or other graphical } \\
\text { display to demonstrate the } \\
\text { data linkage process, } \\
\text { including the number of } \\
\text { individuals with linked data } \\
\text { at each stage. }\end{array}$ & \\
\hline Variables & 7 & $\begin{array}{l}\text { Clearly define all outcomes, } \\
\text { exposures, predictors, } \\
\text { potential confounders, and } \\
\text { effect modifiers. Give } \\
\text { diagnostic criteria, if } \\
\text { applicable. }\end{array}$ & $\begin{array}{l}\text { (7.1) A complete list of } \\
\text { codes and algorithms used } \\
\text { to classify exposures, } \\
\text { outcomes, confounders, } \\
\text { and effect modifiers should } \\
\text { be provided. If these cannot } \\
\text { be reported, an explanation } \\
\text { should be provided. }\end{array}$ & $\begin{array}{l}\text { Patients and } \\
\text { exposure status, } \\
\text { outcomes \& } \\
\text { supplement } 2\end{array}$ \\
\hline $\begin{array}{l}\text { Data sources/ } \\
\text { measurement }\end{array}$ & 8 & $\begin{array}{l}\text { For each variable of interest, } \\
\text { give sources of data and } \\
\text { details of methods of } \\
\text { assessment (measurement). } \\
\text { Describe comparability of } \\
\text { assessment methods if there } \\
\text { is more than one group. }\end{array}$ & & Analysis \\
\hline Bias & 9 & $\begin{array}{c}\text { Describe any efforts to } \\
\text { address potential sources of } \\
\text { bias. }\end{array}$ & & Analysis \\
\hline Study size & 10 & $\begin{array}{l}\text { Explain how the study size } \\
\text { was arrived at. }\end{array}$ & & N/A \\
\hline
\end{tabular}




\begin{tabular}{|c|c|c|c|c|}
\hline $\begin{array}{l}\text { Quantitative } \\
\text { variables }\end{array}$ & 11 & $\begin{array}{l}\text { Explain how quantitative } \\
\text { variables were handled in the } \\
\text { analyses. If applicable, } \\
\text { describe which groupings } \\
\text { were chosen and why. }\end{array}$ & & Analysis \\
\hline Statistical methods & 12 & $\begin{array}{l}\text { (a) Describe all statistical } \\
\text { methods, including those } \\
\text { used to control for } \\
\text { confounding. } \\
\text { (b) Describe any methods } \\
\text { used to examine subgroups } \\
\text { and interactions. } \\
\text { (c) Explain how missing data } \\
\text { were addressed. } \\
\text { (d) If applicable, explain how } \\
\text { loss to follow-up was } \\
\text { addressed. } \\
\text { (e) Describe any sensitivity } \\
\text { analyses. }\end{array}$ & & Analysis \\
\hline $\begin{array}{l}\text { Data access and } \\
\text { cleaning methods }\end{array}$ & & N/A & $\begin{array}{l}\text { (12.1) Authors should } \\
\text { describe the extent to } \\
\text { which the investigators had } \\
\text { access to the database } \\
\text { population used to create } \\
\text { the study population. } \\
\text { (12.2) Authors should } \\
\text { provide information on the } \\
\text { data cleaning methods used } \\
\text { in the study. }\end{array}$ & Access to data \\
\hline Linkage & & N/A & $\begin{array}{l}\text { (12.3) State whether the } \\
\text { study included person- } \\
\text { level, institutional-level, or } \\
\text { other data linkage across } \\
\text { two or more databases. The } \\
\text { methods of linkage and } \\
\text { methods of linkage quality } \\
\text { evaluation should be } \\
\text { provided. }\end{array}$ & $\begin{array}{l}\text { Study design and } \\
\text { setting }\end{array}$ \\
\hline \multicolumn{5}{|l|}{ Results } \\
\hline Participants & 13 & $\begin{array}{l}\text { (a) Report numbers of } \\
\text { individuals at each stage of } \\
\text { study--e.g. numbers } \\
\text { potentially eligible, examined } \\
\text { for eligibility, confirmed }\end{array}$ & $\begin{array}{l}\text { (13.1) Describe in detail } \\
\text { the selection of the persons } \\
\text { included in the study (i.e., } \\
\text { study population selection), } \\
\text { including filtering based on }\end{array}$ & $\begin{array}{c}\text { Baseline } \\
\text { characteristics \& } \\
\text { Fig. } 1\end{array}$ \\
\hline
\end{tabular}




\begin{tabular}{|c|c|c|c|c|}
\hline & & $\begin{array}{l}\text { eligible, included in the } \\
\text { study, completing follow-up, } \\
\text { and analyzed. } \\
\text { (b) Give reasons for non- } \\
\text { participation at each stage. } \\
\text { (c) Consider use of a flow } \\
\text { diagram. }\end{array}$ & $\begin{array}{l}\text { data quality, data } \\
\text { availability, and linkage. } \\
\text { The selection of included } \\
\text { persons can be described in } \\
\text { the text and/or by means of } \\
\text { the study flow diagram. }\end{array}$ & \\
\hline Descriptive data & 14 & $\begin{array}{l}\text { (a) Give characteristics of } \\
\text { study participants (e.g. } \\
\text { demographic, clinical, social) } \\
\text { and information on exposures } \\
\text { and potential confounders. } \\
\text { (b) Indicate number of } \\
\text { participants with missing data } \\
\text { for each variable of interest. } \\
\text { (c) Summarize follow-up } \\
\text { time (e.g. average and total } \\
\text { amount). }\end{array}$ & & $\begin{array}{c}\text { Baseline } \\
\text { characteristics, } \\
\text { mortality and } \\
\text { cardiovascular } \\
\text { outcomes, } \\
\text { Supplement } 3\end{array}$ \\
\hline Outcome data & 15 & $\begin{array}{l}\text { Report numbers of outcome } \\
\text { events or summary measures } \\
\text { over time. }\end{array}$ & & $\begin{array}{l}\text { Postoperative } \\
\text { outcomes, } \\
\text { mortality and } \\
\text { cardiovascular } \\
\text { outcomes } \\
\end{array}$ \\
\hline Main results & 16 & $\begin{array}{l}\text { (a) Give unadjusted estimates } \\
\text { and, if applicable, } \\
\text { confounder-adjusted } \\
\text { estimates and their precision } \\
\text { (e.g. } 95 \% \text { confidence } \\
\text { interval). Make clear which } \\
\text { confounders were adjusted } \\
\text { for and why they were } \\
\text { included. } \\
\text { (b) Report category } \\
\text { boundaries when continuous } \\
\text { variables were categorized. } \\
\text { (c) If relevant, consider } \\
\text { translating estimates of } \\
\text { relative risk into absolute risk } \\
\text { for a meaningful time period. }\end{array}$ & & $\begin{array}{c}\text { Mortality and } \\
\text { cardiovascular } \\
\text { outcomes, Figs. } \\
2-4 \text {, Table } 3\end{array}$ \\
\hline Other analyses & 17 & $\begin{array}{l}\text { Report other analyses done } \\
\text { (e.g. analyses of subgroups } \\
\text { and interactions, and } \\
\text { sensitivity analyses). }\end{array}$ & & $\begin{array}{c}\text { Mortality and } \\
\text { cardiovascular } \\
\text { outcomes, Table 2, } \\
\text { Fig. 5, Supplement } \\
4\end{array}$ \\
\hline
\end{tabular}


Effects of renal-preservation surgery on long-term mortality, CV, \& renal outcomes

\begin{tabular}{|c|c|c|c|c|}
\hline Key results & 18 & $\begin{array}{l}\text { Summarize key results with } \\
\text { reference to study objectives. }\end{array}$ & & Discussion \\
\hline Limitations & 19 & $\begin{array}{l}\text { Discuss limitations of the } \\
\text { study, taking into account } \\
\text { sources of potential bias or } \\
\text { imprecision. Discuss both } \\
\text { direction and magnitude of } \\
\text { any potential bias. }\end{array}$ & $\begin{array}{l}\text { (19.1) Discuss the } \\
\text { implications of using data } \\
\text { that were not created or } \\
\text { collected to answer the } \\
\text { specific research } \\
\text { question(s). Include } \\
\text { discussion of } \\
\text { misclassification bias, } \\
\text { unmeasured confounding, } \\
\text { missing data, and changing } \\
\text { eligibility over time, as } \\
\text { they pertain to the study } \\
\text { being reported. }\end{array}$ & Discussion \\
\hline Interpretation & 20 & $\begin{array}{c}\text { Give a cautious overall } \\
\text { interpretation of results } \\
\text { considering objectives, } \\
\text { limitations, multiplicity of } \\
\text { analyses, results from similar } \\
\text { studies, and other relevant } \\
\text { evidence. }\end{array}$ & & Discussion \\
\hline Generalizability & 21 & $\begin{array}{l}\text { Discuss the generalizability } \\
\text { (external validity) of the } \\
\text { study results. }\end{array}$ & & Discussion \\
\hline \multicolumn{2}{|l|}{ Other information } & 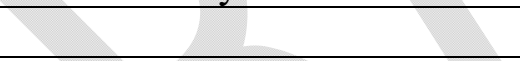 & & \\
\hline Funding & 22 & $\begin{array}{l}\text { Give the source of funding } \\
\text { and the role of the funders for } \\
\text { the present study and, if } \\
\text { applicable, for the original } \\
\text { study on which the present } \\
\text { article is based. }\end{array}$ & & Funding \\
\hline $\begin{array}{l}\text { Accessibility of } \\
\text { protocol, raw data, } \\
\text { and programming } \\
\text { code }\end{array}$ & & N/A & $\begin{array}{l}\text { (22.1) Authors should } \\
\text { provide information on } \\
\text { how to access any } \\
\text { supplemental information } \\
\text { such as the study protocol, } \\
\text { raw data, or programming } \\
\text { code. }\end{array}$ & Access to data \\
\hline
\end{tabular}




\begin{tabular}{|c|c|c|c|}
\hline \multicolumn{4}{|c|}{$\begin{array}{l}\text { Supplementary Table 2: Administrative codes used to define outcomes and validity of } \\
\text { codes }\end{array}$} \\
\hline Outcome & Database & Codes & Validity \\
\hline $\begin{array}{l}\text { All-cause } \\
\text { mortality }\end{array}$ & RPDB & Vital status variable & $\begin{array}{c}\text { Sensitivity: } \\
\text { 94\%1 } \\
\text { PPV: } 100 \% 1 \\
\end{array}$ \\
\hline $\begin{array}{l}\text { Cardiovascular } \\
\text { disease }\end{array}$ & $\begin{array}{l}\text { CIHI- } \\
\text { DAD, } \\
\text { OHIP }\end{array}$ & \begin{tabular}{|c|} 
Myocardial infarction \\
ICD-10: I21, I22 \\
Stroke \\
ICD-10: H341, I630, I631, I632, I633, I634, \\
I635, I638, I639 \\
Coronary angioplasty/ CABG \\
CCI: 1IJ26, 1IJ27, 1IJ50, 1IJ57, 1IJ76 \\
OHIP fee: E646, E651, E652, E654, G262, G298, \\
R741, R742, R743, Z434
\end{tabular} & $\begin{array}{c}\text { Myocardial } \\
\text { infarction } \\
\text { Sensitivity: } \\
89 \% 2 \\
\text { PPV: } 87 \% 2 \\
\\
\text { Stroke } \\
\text { Sensitivity: 75- } \\
81 \% 2 \\
\text { PPV: } 69-87 \% 2 \\
\\
\text { Coronary } \\
\text { angioplasty/ } \\
\text { CABG } \\
\text { Sensitivity: } \\
\text { 99\%2 } \\
\text { PPV: } 100 \% 2 \\
\end{array}$ \\
\hline $\begin{array}{l}\text { Non-cancer } \\
\text { related } \\
\text { mortality }\end{array}$ & $\begin{array}{l}\text { ORGD, } \\
\text { RPDB }\end{array}$ & $\begin{array}{c}\text { Cause of death: cardiovascular } \\
\text { ICD-9: 410, 411, 412, 413, 414, 4296, 4297, 428, } \\
\text { 435, 3623, 4349, 436, 430, 431, 432, 4340, 4341, } \\
426,427,7850,394,395,396,3970,3971,4240, \\
4241,4242,4243,401,402,404,405,4249,425, \\
4291,4292,4293,4294,4295,4298,4299,433, \\
437,438,440,441,442,4431,4438,4439,444, \\
9960, \text { V533, V450 } \\
\text { Cause of death: other } \\
\text { Any other cause of death code or patients with a } \\
\text { death record in RPDB who are missing a cause of } \\
\text { death code in ORGD }\end{array}$ & N/A \\
\hline \begin{tabular}{|l|} 
Kidney \\
cancer-related \\
mortality
\end{tabular} & ORGD & ICD-9: 1890 & $\mathrm{~N} / \mathrm{A}$ \\
\hline
\end{tabular}




\begin{tabular}{|c|c|c|c|}
\hline Any dialysis & $\begin{array}{c}\text { CORR, } \\
\text { CIHI- } \\
\text { DAD, } \\
\text { CIHI-SDS, } \\
\text { OHIP }\end{array}$ & $\begin{array}{c}\text { Treatment Code (CORR): 060, 111, 112, 113, } \\
\text { 121, 122, 123, 131, 132, 133, 141, 151, 152, 211, } \\
\text { 221, 231, 241, 242, 251, 252, 311, 312, 313, 321, } \\
\text { 322, 323, 331, 332, 333, 413, 423, 433, 443, 453 } \\
\text { CCI: 1PZ21 } \\
\text { OHIP FEE: R849, G323, G325, G326, G860, } \\
\text { G862, G865, G863, G866, G330, G331, G332, } \\
\text { G333, G861, G082, G083, G085, G090, G091, } \\
\text { G092, G093, G094, G095, G096, G294, G295, } \\
\text { G864, H540, H740 }\end{array}$ & $\begin{array}{l}\text { Outpatient } \\
\text { dialysis } \\
\text { Sensitivity: } \\
100 \% 3 \\
\text { PPV: } 96 \% 3 \\
\\
\text { Inpatient dialysis } \\
\text { Sensitivity: } \\
93 \% 3 \\
\text { PPV: } 93 \% 3\end{array}$ \\
\hline $\begin{array}{l}\text { Nephrologist } \\
\text { visit }\end{array}$ & $\begin{array}{l}\text { OHIP, } \\
\text { IPDB }\end{array}$ & $\begin{array}{l}\text { OHIP nephrologist specific visit feecode: A160, } \\
\text { A161, A163, A164, A165, A166, A168, A865, } \\
\text { C160, C161, C162, C163, C164, C165, C166, } \\
\text { C167, C169, C865, W165, W160, W865, W166, } \\
\text { W862, W864, W867, W869, W164, W162, } \\
\text { W161, W163, W168 } \\
\text { OHIP internal medicine visit if physician had a } \\
\text { "nephrology" main specialty in IPDB: A130, } \\
\text { A131, A133, A134, A135, A136, A138, A435, } \\
\text { C121, C122, C123, C124, C130, C131, C132, } \\
\text { C133, C134, C135, C136, C137, C138, C139, } \\
\text { C142, C143, C168, C435, C982, W121, W130, } \\
\text { W131, W132, W133, W134, W138, W232, } \\
\text { W234, W235, W236, W237, W239, W435, } \\
\text { W972, W982 }\end{array}$ & N/A \\
\hline
\end{tabular}

1. Jha P, Deboer D, Sykora K, et al. Characteristics and mortality outcomes of thrombolysis trial participants and nonparticipants: a population-based comparison. J Am Coll Cardiol 1996;27:1335-42.

2. Juurlink DN, Preyra C, Croxford R, Chong A, Austin P, Tu JV, et al. Canadian Information Discharge Abstract Database: a validation study. Institute for Clinical Evaluative Sciences 2006. 3. Quinn RR, Laupacis A, Austin PC, et al. Using administrative datasets to study outcomes in dialysis patients: A validation study. Med Care 2010;48:745-50.

CABG: coronary artery bypass graft surgery; CCI: Canadian Classification for Health Interventions; CIHI-DAD: Canadian Institute for Health Information's Discharge Abstract Database; CIHI-SDS: Canadian Institute for Health Information's Same Day Surgery database; CORR: ICD-9, 9th edition of the Canadian Modified International Classification of Disease system; ICD-10: 10th edition of the Canadian Modified International Classification of Disease system; IPDB: ICES Physician Database; OHIP: Ontario Health Insurance Plan; ORGD: Office of the Registrar General; PPV: positive predictive value; RPDB: Registered Persons Database. 
Effects of renal-preservation surgery on long-term mortality, CV, \& renal outcomes

\begin{tabular}{|c|c|c|}
\hline \multicolumn{3}{|c|}{$\begin{array}{l}\text { Supplementary Table 3. Distribution of followup times } \\
\text { for all-cause mortality in years }\end{array}$} \\
\hline Followup time (years) & Partial & Radical \\
\hline Mean (SD) & $7.1(2.3)$ & $7.2(3.3)$ \\
\hline Median (IQR) & $6.9(5.3-8.4)$ & $7.2(5.1-9.5)$ \\
\hline Min & 0.03 & 0.01 \\
\hline $\operatorname{Max}$ & 13.1 & 13.8 \\
\hline
\end{tabular}

IQR, interquartile range; SD, standard deviation.

\begin{tabular}{|l|c|c|}
\hline \multicolumn{2}{|c|}{ Supplementary Table 4. 1-, 5- and 9-year cumulative incidence of all-cause mortality } \\
\hline & Partial & Radical \\
\hline 1-year cumulative incidence & $0.3 \%$ & $2.4 \%$ \\
\hline 5-year cumulative incidence & $5.3 \%$ & $11.8 \%$ \\
\hline 9-year cumulative incidence & $20.0 \%$ & $22.2 \%$ \\
\hline
\end{tabular}

\begin{tabular}{|l|c|}
\hline $\begin{array}{l}\text { Supplementary Table 5. Hazard ratios for secondary outcomes using Fine and } \\
\text { Gray's Model with competing risk of death }\end{array}$ \\
\hline Outcome & $\begin{array}{c}\text { Hazard ratio } \\
\mathbf{( 9 5 \%} \text { confidence interval) }\end{array}$ \\
\hline Hospitalization with major cardiovascular event & $1.28(0.79,2.07)$ \\
\hline Non-cancer-related mortality & $0.86(0.59,1.25)$ \\
\hline Kidney cancer-related death & $\begin{array}{c}\text { 0-<4 years: } 0.12(0.03,0.55) \\
\text { 4+ years: } 0.87(0.22,3.46)\end{array}$ \\
\hline
\end{tabular}

